УДК $159.92 ; 316.62$

doi: $10.15330 / p s .10 .1 .45-54$

Світлана Литвин-Кіндратюк

ДВНЗ «Прикарпатський національний університет імені Василя Стефаника»

lytvynkindr@ukr.net

\title{
МЕТОДОЛОГІЧНІ ЗАСАДИ ДІАХРОНІЧНОГО АНАЛІЗУ РОЗВИТКУ ОСОБИСТОСТІ В ПСИХОЛОГІї
}

У статті розкривається стратегія організації дослідження в галузі соціальної історичної психологї̈ на засадах збагачення змісту принципу історизму та поля понять, щуо описують логіку «історіоризації» особистості у світі, щуо стрімко змінюється. Окреслено способи організації дослідження, які містять варіанти синхронічного та діахронічного способів аналізу. Показано, щзо у прочесі розвитку особистості в онтогенезі елементи діахронічного розгляду є складовою синхронічного трактування отриманих результатів, оскільки у його перерізі маркується дискретна мить історії в шерезі подій життя певного покоління та на тлі сучасної сочіальної ситуації розвитку. Натомість діахронічний аналіз визначено різновидом стратегії «аналізу процесів», щзо звернутий до вимірів історичного процесу. Він апелює до окремого типу розвитку - історіогенезу особистості, якому притаманні гетерохронність, міжпоколіннєва спадкоємність та соціокультурна контекстуальність. Окреслено види діахронічного аналізу: «масштабний» та «локальний», «близький» та «віддалений». Діахронічний аналіз в соиіальній історичній психології визначено стратегією організації дослідження, яка спирається на фігуративні реконструктивні процедури, насамперед метод психолого-історичної реконструкиії. Розкрито основне завдання діахронічного аналізу, яке полягає в переході від лінійного до нелінійного аналізу сталості-змінюваності сторичного розвитку особистості, насамперед у контексті домінування процесів сочіогенезу та культурогенезу. Оновлення їхніх конфігуращій виявляється в соціальних змінах у рамках множинного сочіального часу та культурних фігураціях стабільних форм поведінки особистості.

Ключові слова: принции історизму, історіогенез особистості, діахронічний аналіз, соціальна історична психологія, міжпоколіннєва спадкоємність, контекстуальність.

Постановка проблеми. На тлі прискорення соціокультурних змін та ускладнення форм стабілізації соціальної поведінки актуальності набуває проблема «історіоризації» розвитку особистості у психології. Вивчення розвитку особистості у вимірах історії викликає інтерес не лише у фахівців з вікової та соціальної психології, що дозволило, приміром, поглянути на феномен віку з соціокультурних позицій, а й сприяє розширенню предметного поля історичної психології.

Свідченням поступу на теренах української та зарубіжної історичної психології стало утвердження іiі методологічних принципів, головно принципу історизму, становлення низки міждисциплінарних напрямів та розробка оригінальних теорій (І. Бєлявський, I. Мейєрсон, В. Роменець, В. Шкуратов та інші) [2; 29, 85; 25], створення оригінальних реконструктивних методів та методик. Водночас найменш опрацьованою ланкою на цьому терені залишаються стратегії організації психолого-історичного дослідження. Не викликає сумнівів, що іï різні види спрямовані на розкриття закономірностей як онтогенезу, так й історіогенезу психіки та особистості. Проте нині бракує чіткого розмежування мети та завдань цих стратегій, приміром, у форматі синхронічного та діахронічного способів аналізу.

Відомо, що ідея розвитку психіки й особистості, принципи та категорії розвитку в наш час найбільш широко реалізовані у синхронічних дослідженнях, а саме: у царині дитячої, вікової психології та психології розвитку. Проте намагання сформулювати закономірності розвитку особистості в сув'язі ліній - когнітивної, емоційної, соціальної частогусто наштовхуються на проблему стабільності та мінливості. С. Максименко вважає, що співвідношення стабільного і змінного залишається надскладною проблемою теоретичної психології, яка потребує свого розв'язання. Вчений підкреслює, що стійкі властивості, узагальнені емоційно-чуттєві стосунки і стабільні психічні стани завжди мають процесуально-динамічний характер [13]. 
На думку дослідників, вивчення взаємозв'язку процесів сталості та мінливості у плині еволюційного розвитку психіки й особистості потребує розширення спектру способів організації генетико-психологічного дослідження. Так, поглиблення трактування розвитку в сучасній психології, зокрема 3 позицій системно-синергетичного підходу, сучасних наук про розвиток загалом закономірно ставить питання про особливості його розгортання не лише у синхронічному зрізі, але й у діахронічному, історичному перерізі. Йдеться про вивчення тенденцій та закономірностей історичного розвитку особистості в режимі лінійних прогресивних, регресивних та змішаних рівнинних типів.

Нині у фокус психолого-історичного пошуку потрапляють різноманітні типи, види, аспекти, варіанти психічного розвитку особистості, насамперед соціального, що розгортаються в умовах еволюційних та катастрофічних змін, трансформацій та екстремальності. Вкупі вони становлять поле соціально-психологічних процесів, що мають розмаїте «темпоральне напруження» та кліодинаміку - темп і масштаб, тобто поле соціально-історичного розвитку особистості. Аналіз соціального розвитку особистості на тлі швидкоплинних соціальних змін, зокрема в форматі історичного способу життя того чи іншого покоління, потребує відповідних цим феноменам методологічних інструментів, які були б здатні поглибити діалектичний метод або ж примножити можливості еволюційних підходів.

Мета статті полягає у спробі накреслити методологічні засади діахронічного дослідження особистості в історичному ракурсі. Для іiі досягнення були поставлені наступні завдання: 1) окреслити мету та завдання діахронічного аналізу як основного способу організації дослідження в соціальній історичній психології; 2) визначити види діахронічного аналізу та сутнісні характеристики розвитку особистості в історії.

Стан дослідження проблеми. В українській психології лінія дослідження історичного розвитку особистості має поважні традиції. Вона спрямована на пошук рис стабільності в поступальному розвитку, його видів та типів. Зазначений кут зору був накреслений у працях С. Рубінштейна [19], отримав подальший розвиток у історико-психологічних шуканнях Г. Костюка [9], став складовою частиною концепції вчинку В. Роменця [18]

У довідковій психологічній літературі студії на теренах розвитку психіки зазвичай позначаються трьома основними лініями, а саме: 1) виникнення психіки у тваринному світі; 2) розвиток психіки в онтогенезі людини; 3) виникнення (антропогенез) і розвиток (історіогенез) свідомості людини [17, с. 305]. Зразу зауважимо, що на теренах антропогенезу десятиліття поспіль перед ведуть розвідки виникнення свідомості та адаптивних форм поведінки (Г. Костюк, Б. Поршнєв) [9; 17], тоді як їхнє розмаїття в історіогенезі та у річищі соціогенезу досліджуються швидше епізодично.

Накреслюючи лінію історичності розвитку особистості, С. Рубінштейн дійшов висновку, що, по-перше, внаслідок історичної зумовленості в психології особистості виявляються компоненти різної міри узагальненості та сталості, які змінюються різними темпами [19, с. 270], по друге, «у психіці людей є властивості, які суттєво змінюються в ході історичного розвитку людства та які відрізняють людей різних епох» [19, с. 169]. 3 розбудовою історичної психології прийоми історичного пошуку почали застосовуватися 3 метою дослідження історії розвитку психіки, особистості, соціальних спільнот, тобто до тих об'єктів, що мають історичний характер. Їх можна порівнювати 3 певними історичними змінами за тривалістю, за особливостями темпоральної структури та характером змін. Висунуті Л. Виготським теоретичні положення про те, що «поведінка може бути зрозуміла лише як історія поведінки» [3, с. 62] стали основою розробки вченим історикогенетичного та експериментально-генетичного методів, які поєднують прийоми синхронічного та діахронічного аналізів.

Справжній ренесанс діахронічних студій в українській психології припадає на початок 80-х років минулого століття. Панорама історико-психологічних шукань В. Роменця вміщає глибокий аналіз соціально-історичного типу розвитку особистості на засадах вчинкового підходу. Вчений описав не лише розмаїття явищ цього розвитку, а й проана- 
лізував учинок в контексті способу життя як осередок розвитку особистості в історії. Водночас у процесі послідовної реалізації вчинкового підходу гостро постала потреба розрізнення теоретико-методологічних засад розвитку особистості крізь призму генетичної синхронічності й психолого-історичної діахронічності.

У психолого-історичних працях В. Роменця червоною ниткою проходить ідея системи психології на засадах оригінального варіанту діахронічного аналізу. В ній поєднується логічне та історичне, що представлені у структурі вчинку. Логічна структура вчинку визначена як стабільна та інваріантна. Вона містить обов'язкові компоненти ситуативний, мотиваційний та дійовий, натомість історичний вияв цієї структури розкриває рівень зрілості вчинку в діахронії [18, с. 18].

У сучасному психолого-історичному дискурсі представлені різні погляди стосовно теоретичного та методичного забезпечення синхронічного та діахронічного аналізів. Терміни «діахронія», «діахронічність» прийшли до нас з історичної лінгвістики. Діахронія (від діа- + гр. chronos = час) - це лігвістичний термін, який означає історичну послідовність у розвитку мовних явищ. Тому діахронічний - той, що стосується діахронії, тобто розглядається з урахуванням фактору часу, (наприклад, метод вивчення) [16, с. 203]. Йому протиставляється синхронія (гр. synchronos, від. $\quad$ syn $=$ разом + chronos=чаc) - той, що збігається в часі, одночасний. Синхронічний - це той, що вказує на синхронізм, одночасність, наприклад, методу [16, с. 562]. У психології перший термін розрізняє послідовність, впорядкованість явищ у часі, маркує їх еволюційну спрямованість та історичну стадіальність, натомість другий термін за своїм характером є швидше аісторичний, оскільки фокусує не еволюційні, а порівняльні аспекти розвитку.

Водночас у науковій літературі знаходимо різні трактування діахронічного варіанту аналізу розвитку особистості, зокрема опису його мети та завдань. В одних випадках він вважається частиною синхронічного способу аналізу, у інших - навпаки. У студіях культурно-історичного спрямування діахронічний розвиток згадується як складова синхронічного розвитку (3. Карпенко, М. Коул) [8; 10], натомість у історичній психології діахронічна лінія розвитку особистості домінує. Про необхідність врахування діахронічної структури розвитку особистості вслід за П. Бальтесом говорить Л. Анциферова та інші автори [1]. До кола питань, що потребують застосування прийомів діахронічного аналізу, вони відносять такі: структура цілісного життєвого шляху індивіда, типологія таких структур, суспільно-історична (формаційна - розрядка наша Л.-К. С.) зумовленість фаз, етапів, стадій індивідуального шляху розвитку особистості» [1, с. 9].

Наприкінці XX століття вирішальним для історичного повороту в психології став новаторський рух європейських соціальних психологів, які з 70 -х років минулого століття почали відстоювати контекстуальність пошуків у цій галузі (С. Московічі, А. Теджфел та інші) $[15 ; 21]$. Їм передувало оформлення історичної психології як самостійної психологічної галузі (І. Мейєрсон) [29]. Активізація постмодерного дискурсу теж сприяла прихильності соціальних психологів, передовсім соціальних конструкціоністів, до перегляду наукових уявлень про соціально-психологічний розвиток у бік історизму. Лідер цього напряму К. Герген вважає, що соціальній психології відчутно бракує знань динаміки та трансформацій соціальних процесів, що мають історичний характер [28]. Помітне зростання інтересу дослідників до проблем історіогенезу особистості, до трансформацій стабільної соціальної поведінки відбулося у зв'язку з різноаспектним вивченням процесу зародження нових моделей соціальної реальності у соціології (Дж. Александер, П. Штомпка) [27; 26], соціальній і культурній психології (М. Гусельцева, В. Москаленко, Т. Титаренко) [5; 14; 23].

Нинішній поступ психолого-історичних студій поєднується із міжгалузевими шуканнями в межах загальної психології, вікової психології, соціальної психології та етнопсихології тощо. Стає очевидним, що окремі концепції розвитку особистості насичені психолого-історичними ідеями та положеннями. Водночас вони часто-густо відстоюють власне бачення діахронічного аналізу, що дозволяє, приміром, отримувати значущі ре- 
зультати про закономірності онтогенезу психіки у його зв'язку із процесами соціогенезу чи етногенезу (І. Данилюк, В. Куєвда) [6; 12]. Тому однією з причин поширення своєрідного «методологічного нігілізму» серед психологів, про який говорить А. Шамне, слід вважати брак знань про психологічні закономірності розвитку особистості в історії. А. Шамне відзначає девальвацію фундаментальної ідеї розвитку в психології. На іiї думку, протидія цій тенденції неможлива без ретельної методологічної реконструкції категорії розвитку в психології [24, с. 23]. Вона вважає, що система принципів психології розвитку, яке поєднує принцип розвитку, системності, суб'єктності, неперервності здатна змінити свою методологічну конфігурацію, в якому панували дихотомії соціальне-біологічне, об'єкт-суб'єкт, каузальне-стохастичне.

Підтримуючи позицію А. Шамне, міркуємо, що у разі переходу від синхронічного до діахронічного аналізу розвитку особистості домінування принципу історизму у цій методологічній схемі стає очевидним. Це надає характеристикам сталості-змінності цього процесу сутнісної ваги та локалізує їх у полі предмету соціальної історичної психології. Остання налаштована на вловлювання довгих темпоральних змін, стабільних форм існування особистості в соціальній спільноті у масштабах «спокійних» епох та перехідних історичних періодів. Її пошук спрямований на з'ясування закономірностей історичного, соціального, екологічного, психічного розвитку в їхній коеволюції, вивчення історіогенезу особистості та соціальних спільнот.

Пошук шляхів більш повного аналізу історіогенезу особистості спрямовує в бік діахронного аналізу цих перетворень не лише психологів, а й істориків, соціологів [17; 22; 25]. При цьому вчені по-різному розуміють логіку історичного процесу, пропонують відмінні стратегії його моделювання та способи обробки даних, що не завжди є запорукою відкритого й зацікавленого діалогу представників цих наук. Проте у сучасній історичній соціології вже утвердилася низка методичних моделей аналізу історичного розвитку, які можуть стати основою організації соціально-психологічного дослідження такого типу. 3 цього приводу прислухаємося до думки одного 3 лідерів історико-соціологічного пошуку Ч. Тіллі. Німецький учений називає чотири основні історико-соціологічні способи аналізу, які представляють стратегії наукового пошуку, як от: «Історичний соціальний критицизм», «Ідентифікація патернів», «Розширення масштабів», «Аналіз процесів». Усі ці стратегії, зазначає вчений, є вже «визнаними, ефективними формами соціологічного аналізу, проте вони відрізняються за цілями, процедурами й результатами» [22, с. 96].

Так, для історичного соціального критицизму, що широко використовувався соціологами упродовж XIX ст., властиві «спроби знайти краще вирішення дилем часу та напрям розвитку людства шляхом постановки теперішнього в межі тривалих крупних соціальних процесів» [22, с. 96]. У межах першої стратегії мета має аксіологічну перспективу. Йдеться про вивчення успіхів і невдач минулого та пошуку шляхів їхнього запобігання в майбутньому людства (К. Маркс, М. Вебер та інші). Друга стратегія - «Ідентифікація патернів» наполягає на аналізі структур і ланцюгів історичних подій, що повторюються в часі і просторі, визначенні необхідних та достатніх умов цих повторень $\mathrm{i}$ встановлення їхньої послідовності. Стратегія базується на вивченні історії крупних агрегатів, приміром, фаз розвитку цивілізації (П. Сорокін), або процесів у межах окремих країн та регіонів, зокрема динаміки економічного росту (цикли Кондратьєва), секуляризації, росту населення тощо. Третя стратегія - «Розширення масштабів» (scope extension) апелює до аналізу історичних ситуацій. Вона послуговується низкою технік, моделей та узагальнень, що були створені для вивчення сучасного життя суспільства (використовується в історичній демографії, історії сім'ї тощо).

Четверта стратегія «Аналіз процесів» здебільшого орієнтована на перевірку впливу соціальних інтеракцій у часі і просторі. У їі межах припускається, що просторово-часові зв'язки визначають соціальні процеси, оскільки останні відбуваються по-різному як функція їхнього часу й простору [22, с. 97]. У річищі четвертої стратегії перед ведуть дослідники глобалізації та урбанізації. На думку Ч. Тіллі, на найвищу оцінку заслуговує 
остання стратегія. Адже «з чотирьох різновидів історичної соціології аналіз процесів безпосередньо втягує соціологів у розуміння історії як історії, тобто вбудовування дій людей у просторі та часі» [22, с. 99]. Короткий опис згаданих стратегій свідчить, що всі вони можуть бути адаптовані для застосування у процесі діахронічного аналізу у психології.

Виклад основного матеріалу. Сучасні науки, теорії й концепції людського розвитку дедалі повніше враховують соціально-психологічну перспективу та історичну ретроспективу аналізу розвитку особистості. Це сприяє перегляду та розширенню змісту принципу розвитку та історизму в сучасній психології, уточненню стратегій організації дослідження на цій основі. Вони пов'язуються із соціальними змінами, що мають культурний та історичний характер, розгортаються в багатошаровому соціальному та історичному часі - в організації структури суспільства, взірцях мислення та культури, соціальній поведінці та підпорядковуються логіці полі- та міжсистемної взаємодії. Теоретичним моделям такого плану властиві як опора на побудову типологій особистості, приміром, у форматі iї цілісності (О. Власова) [4], так і на опис конфігурацій у динамічних системах «особистість-соціалізація» (В. Москаленко) [14].

За дороговказ діахронічного пошуку в психології приймаємо принцип історизму. Зміст цього принципу пов'язуємо не з положеннями формаційного підходу, а з сучасними уявленнями про закономірності історичного процесу. На цих засадах визначимося з метою історіогенетичного аналізу, його загальною спрямованістю та різновидами. Йдеться про відмінності його синхронічного та діахронічного варіантів.

Спираючись на пропоноване I. Білявським тлумачення принципу історизму, вважаємо, що соціально-психологічне дослідження історичного розвитку особистості може бути організоване двояко - горизонтально, тобто синхронічно, метою якого є опис історичного епізоду у складі соціогенезу, та вертикально, діахронічно, метою якого $\epsilon$ вивчення історіогенетичної лінії розвитку особистості в міжпоколінній послідовності. Очевидно, що студії розвитку особистості в діахронії, тобто на тлі історичної епохи, іiї ментальності є найбільш повним варіантом історіогенетичного аналізу. Їх завданням є розширення панорами наукових пошуків щодо характеру та механізмів психічного розвитку, зокрема історіогенезу емоцій, характеру, соціальної поведінки особистості на тлі історичних змін тощо. Міркуємо, що система принципів психології розвитку, яке поєднує принцип розвитку, системності, суб'єктності, неперервності здатна змінити свою методологічну конфігурацію, в якій панували дихотомії соціальне-біологічне, об'єкт-суб'єкт, каузальне-стохастичне. На нашу думку, в разі переходу від синхронічного до діахронічного дослідження розвитку має місце домінування принципу історизму, відтак у цьому ансамблі дихотомія «сталість-мінливість» набуває провідного значення.

У подальшій розробці методичних засад діахронічного аналізу опираємося насамперед на соціологічну стратегію «Аналіз процесів». На цій основі опишемо види діахронічного аналізу особистості у психології. За критерієм охоплення історичних періодів та епох виокремимо більш «масштабний» та «локальний» варіанти діахронічного аналізу, натомість за критерієм історичної дистанції (стосовно позиції дослідника) - «близький» та «віддалений» його варіанти. У діахронії життєвого шляху аналізується культурно-історичний, історико-персонологічний розвиток особистості, що дозволяє виокремити вслід за С. Кримським варіанти «малого» та «великого» діахронічного аналізу часу життя поколінь [11]. Перший зорієнтований на вивчення історії життя особистості в межах одного покоління, тобто «коротких» хвиль соціальних змін. Другий спрямований на психологоісторичну реконструкцію розвитку особистості в мережі історичних тривалостей, «довгих хвиль» змін міжпоколінних взаємодій. Загалом діахронічний аналіз у психології спрямований на вивчення як історії життя особистості, так і людини в історії.

3 огляду на особливості процесу «історіоризації» персонологічних студій, враховуючи відповідні їм методичні прийоми вивчення особистості, сформулюємо загальний погляд на зміст синхронічного та діахронічного аналізу. Міркуємо, що горизонтальний 
переріз розгляду історіогенезу переважає в межах синхронічного аналізу, де він представлений точково - як індивідуально-типологічна форма в межах соціальної ситуації розвитку. Тоді він фактично зводиться до соціогенезу особистості. Інакше кажучи, у синхронічному перерізі маркуємо дискретну мить історії в шерезі подій життя певного покоління, на тлі соціальної ситуації розвитку в межах онтогенетичної лінії розвитку. Поперечне, синхронічне дослідження історичного розвитку особистості має на меті врхувати історичний контекст її розвитку, вплив ментальності тієї чи іншої епохи на особисту історію життя, що вказує на включення фрагменту «великого» діахронічного аналізу в контекст «малого» формату. Тому у більшості генетичних студій принцип історизму реалізується головно на мікрорівні соціальної та культурної взаємодії. У вузькому значенні він стосується того виміру історичності структури особистості, який типологічно представлений як соціокультурний аспект віку, а в індивідуально-типологічному аспекті тип особистості, iї типові риси чи неповторна історія життя особи. Це є прикладом діахронії в межах синхронічного дослідження.

Натомість діахронічний аналіз розвитку особистості належить до предметного поля соціально-історичної психології. Він підпорядковуються іiі категоріальному ладу, герменевтичній методології, історико-реконструктивному методу. Тут домінує категорія «історичний процес» на противагу «соціально-економічній формації», уявлення про сталий розвиток на противагу абсолютизації прогресу, неперервність та дискретність історичного розвитку на противагу боротьбі протилежностей.

У діахронічному зрізі історіогенез особистості представлений полілінійною динамікою - підйомами, спадами, коловоротами. Нелінійність вертикального зрізу історіогенезу проявляється у сув'язі фігурацій культурних поведінкових форм (соціальних практиках) в межах історичного процесу та їхніх конфігураціях (результатах). Відтак діахронічний аналіз у психології $\epsilon$ способом організації дослідження, який спирається головно на фігуративні та конфігуративні реконструктивні процедури. При цьому він апелює до їхньої темпоральної гетерогенності (гетерохронності). Останню слід вважати провідною характеристикою соціально-темпоральних, тобто історичних феноменів. У випадку психологічного аналізу макрочасу історії перед нами окреслюється особливий різновид гетерохронності розвитку особистості - діахронічний, який, на нашу думку, представлений циклічним, сталим (збалансованим) та прогресивним розвитком.

Метою діахронічного аналізу є вивчення історіогенезу особистості, зокрема на рівні історії та культури побуту, життєдіяльності особистості та соціальних спільнот. Його основне завдання полягає у вивченні розвитку особистості в історичному часі, плин якого виявляється нелінійним і гетерохронним. Діахронічний аналіз орієнтований на принцип історизму, оскільки історіогенез представлений континуальною сув'яззю його сторін в масштабі історичного простору та контексті соціальних практик.

Вслід за Н. Еліасом логіку поєднання характеристик сталості та змінності вбачаємо у плинності зв'язків (фігураціях) соціогенезу та персоногенезу, насамперед зміні поведінкових форм, їх результат - в конфігураціях сторін історіогенезу, а методику дослідження - у фігуративному аналізі [7]. Фігурації Н. Еліас розглядає на рівні структури соціальних інститутів та манер поведінки, їх взаємовпливу. Тоді як соціально-психологічний погляд на процес фігурування змінюється. По-перше, він має на меті розгледіти більш глибокі психологічні пласти динаміки розвитку особистості, іiі поведінки на тлі історичних змін; по-друге, передбачає ретельне опрацювання репертуару сталих чи змінних поведінкових форм, варіантів соціальних змін, їхньої когерентності з психологічними в аспекті регулярності - темпу, ритму, фігурацій. Означена когерентність має соціокультурний, історичний характер, оскільки є критерієм процесу історіогенезу особистості.

Введення соціально-історичного виміру аналізу розвитку особистості дозволить перейти до більш успішного іiі розв'язання у соціальній психології - у контексті соціальних змін як перебігу множинного соціального часу. Соціально-історичний розвиток особистості пов'язуємо зі змінами спрямованості соціального розвитку, трансформаціями 
способу життя, зокрема його соціокультурного змісту та структури. При цьому феноменологія способу життя володіє не лише синхронним розмаїттям, а й значною соціальноісторичною глибиною, у якій криється системна «одиниця» аналізу соціально-історичного розвитку особистості - феномен міжпоколінної взаємодії. Апелюючи до евристичних можливостей історико-соціологічної фігуративної методології, усвідомлюємо іiі віддаленість від соціально-психологічної методики. Тож першим кроком у напрямі соціальнопсихологічної та психолого-історичної конкретизації фігуративного аналізу став, поперше, вибір за основу комплементарної ій стратегії «Аналіз процесів»; по-друге, опис низки класифікацій діахронічного аналізу в ії контексті.

Висновки. Порівняння стратегій організації дослідження у психології розвитку дозволяє окреслити їх діахронічні різновиди, зокрема «масштабний» та «локальний», «близький» та «віддалений». Вони реалізуються за двома основними лініями: макроаналізу розвитку особистості на тлі історії та цивілізаційних змін; мікроаналізу розвитку у масштабах життя людини. Стратегії мікроаналізу тяжіють до синхронічного розгляду й опираються насамперед на культурно-історичну та новочасну методологічну традицію у психології розвитку. Вони характеризуються спрямованістю на вивчення закономірностей розвитку в рамках віку за логікою «прогрес-акме-згасання» та «постійний саморух», а також історії життя особистості (індивідуальний, позавіковий розвиток). У вивченні процесу розвитку особистості в онтогенезі використовуються елементи діахронічного розгляду. Проте вони є складовою частиною синхронічної інтерпретації отриманих результатів, оскільки у іiї перерізі маркується дискретна мить історії в шерезі подій життя певного покоління на тлі сучасної соціальної ситуації розвитку.

В історичній психології діахронічний аналіз є провідною стратегією організації дослідження. 3 соціально-психологічного боку його можна вважати різновидом стратегії «аналізу процесів», що звернутий до вимірів історичного процесу. Зазначена стратегія апелює до окремого типу розвитку - історіогенезу особистості, якому притаманні гетерохронність, міжпоколіннєва спадкоємність та соціокультурна контекстуальність. Ідеться про те, що діахронічний аналіз оперує власними «одиницями» аналізу (міжпоколінна взаємодія) та сутнісними характеристиками (контекстуальність). Він є стратегією організації дослідження, яке спирається на фігуративні реконструктивні процедури, насамперед метод психолого-історичної реконструкції. Основне завдання діахронічного аналізу полягає в переході від лінійного до нелінійного аналізу сталості-змінюваності історичного розвитку особистості, насамперед у контексті домінування процесів соціогенезу та культурогенезу.

1. Анцыферова, Л. И., Завалишина, Д. Н., Рыбалко, Е .Ф. (1988). Категория развития в психологии. Категории материалистической диалектики в психологии. М.: Наука. С. 22-55.

2. Белявский, И. Г. (2002). Введение в историческую психологию. Одесса.

3. Выготский, Л. С. (1983). История развития высших психических функций Собрание сочинений: в 6-ти т. Т. 3. Проблемы развития психики; под ред. А. М. Матюшкина. М.: Педагогика. С. 6-328.

4. Власова, О. І. Ващенко, І. В. Данилюк, І. В. Щербина, В. Л. (2016). Досвід міждисциплінарного дослідження цілісності особистості в контексті соціальних змін. Психологія і особистість, 2, 1, 116-127.

5. Гусельцева, М. С. (2011). Психологическое знание и культурно-историческая эпистемология. Вопросы психологии, 3, 3-16.

6. Данилюк, І. (2010). Етнічна психологія як галузь наукового знання : історико-теоретичний вимір: монографія. К.:«САММІТ-КНИГА».

7. Еліас, Н. (2003). Процес иุивілізації. Соціогенетичні та психогенетичні дослідження. Київ: Видавничий дім «Альтернатива».

8. Карпенко, 3. (2018). Аксіологічна психологія особистості: монографія. 2-ге вид. перероб., доповн. Івано-Франківськ: ДВНЗ «Прикарпатський національний університет імені Василя Стефаника».

9. Костюк, Г. С. (1988). Избранные психологические труды. М.: Педагогика.

10. Коул, М. (2007). Переплетение филогентической и культурной истории в онтогенезе. Культурно-историческая психология, 3, 3-16.

11. Кримський, С. (2003). Запити філософських смислів. К.: Вид. ПАРАПАН. 
12. Куєвда, В. Т. (2012). Рефлексія етнокультурних домінант в українській психологічній думці: історико-психологічний вимір. Історико-психологічна реконструкиія психологічної думки в етнокультурному вимірі: монографія. В. Т. Куєвда, В. В. Турбан (Ред.). Кіровоград: Імекс-ЛТД.

13. Максименко, С. Д. (2006). Генеза здійснення особистості. К.: Вид. ТОВ «КММ».

14. Москаленко, В. (2012). Значення генетичної методології в дослідженні соціалізації особистості Соиіальна психологія. 1-2, 3-10.

15. Московичи, С. (1995). Социальные представления: исторический вигляд. Психологический журнал, 1, 3-18; 2, 3-14.

16. Новий словник іншомовних слів: близько 40000 сл. і словосполучень (2008) / за заг. ред. Л. І. Шевченко. К.: АРІЙ.

17. Поршнев, Б. Ф. (1979). Социиальная психология и история. М.: Наука.

18. Роменець, В. А. (2006). Вчинок і постання канонічної психології. Людина. Суб'єкт. Вчинок: Філософсько-психологічні студії / за заг. ред. В. О. Татенка. К.: Либідь, С. 11-36.

19. Рубинштейн, С. Л. (1989). Основы общей психологии; В 2 т. Т.1. М.: Педагогіка.

20. Психологічна енциклопедія (2006). Автор-упорядник О. М. Степанов. К.: Академвидав.

21. Тэшфел, А. (1984). Экмперименты в вакууме Социальна зарубежная сочииальная психология / под ред. Г. М. Андреевой, Н. Н. Богомоловой, Л. А. Петровской. М.: Изд-во Моск. ун-та, С. 229-243.

22. Тилли, Ч. (2009). Историческая социология. Социологические исследования, 5, 95-101.

23. Титаренко, Т. М. (2014) Нариси до соціально-психологічної теорії особистісного життєконструювання Збірник науковий статей Київського міжнародного університету $і$ інституту соціальної та політичної психологї̈ НАПН України. Серія: «Психологічні науки: проблеми, здобутки». Випуск 5. К.: КиМу, С. 172-186.

24. Шамне, А. (2017). Інтерпретація категорії розвитку у сучасній психології. Психологія особистості, 1, 22-30. ЮФУ.

25. Шкуратов, В. А. (2004). Новая историческая психология: монографія. Ростов-на-Дону: Изд-во

26. Штомпка, П. (1996). Социология социальных изменений. М.: Аспект Пресс.

27. Alexander, J. C. (2006). Cultural Pragmatics: social performance between ritual and strategy Social Performance: Symbolic, Action, Cultural Pragmatics and Ritual / Ed. by Jeffrey C. Alexander, Bernhand Giesen, Jason L. Mast. Cambridge: Cambridge Universitet Press, pp. 29-90.

28. Gergen, K. J. (2001). Social Construction in Context. London: SAGE Publications.

29. Meyerson, I. (2014). Les fonctions psychologiques et oeuvres. Paris, Albin Michel.

\section{REFERENCES}

1. Antsyferova, L. I., Zavalishyna, D. N., Rybalko, E. F. (1988). Kategoriya razvitiya v psihologii [The category of development in psychology]. Kategorii materialisticheskoy dialektiki v psihologii [The categories of materialistic dialectics in psychology]. Moskva: Nauka, pp. 22-55. (rus.).

2. Belyavskiy, I. G. (2002). Vvedenie v istoricheskuyu psihologiyu [Introduction to historical psychology]. Odessa. (rus.).

3. Vygotskiy, L. S. (1983). Istoriya razvitiya vyisshih psihicheskih funktsiy. Sobranie sochineniy [The history of the development of higher mental functions. Collected Works]: v 6-ti t. T.3. Problemy razvitiya psihiki [Problems of development of the psyche]. A. M. Matyushkin (Ed.). Moskva: Pedagogika, pp. 6-328. (rus.).

4. Vlasova, O. I., Vashchenko, I. V., Danyliuk, I. V., Shcherbyna, V. L. (2016). Dosvid mizhdystsyplinarnoho doslidzhennia tsilisnosti osobystosti v konteksti sotsialnykh zmin [Experience of interdisciplinary study of personality integrity in the context of social change]. Psykholohiia i osobystist [Psychology and personality], 2, 1, 116-127. (ukr.).

5. Guseltseva, M. S. (2011). Psihologicheskoe znanie i kulturno-istoricheskaya epistemologiya [Psychological knowledge and cultural and historical epistemology]. Voprosy psihologii [Issues of psychology], 3, 3-16. (rus.).

6. Danyliuk, I. (2010). Etnichna psykholohiia yak haluz naukovoho znannia : istoryko-teoretychnyi vymir: monohrafiia [Ethnic psychology as a branch of scientific knowledge: historical and theoretical dimension: monograph]. Kyiv: «SAMMIT-KNYHA». (ukr.).

7. Elias, N. (2003). Protses tsyvilizatsii. Sotsiohenetychni ta psykhohenetychni doslidzhennia [The process of civilization. Sociogenetic and psychogenetic studies]. Kyiv: Vydavnychyi dim «Alternatyva». (ukr.).

8. Karpenko, Z. (2018). Aksiolohichna psykholohiia osobystosti: monohrafiia [Axiological psychology of personality: monograph]. 2-he vyd. pererob., dopovn. Ivano-Frankivsk: DVNZ «Prykarpatskyi natsionalnyi universytet imeni Vasylia Stefanyka». (ukr.).

9. Kostyuk, G. S. (1988). Izbrannyie psihologicheskie trudyi [Selected psychological works]. Moskva: Pedagogika. (rus.).

10. Koul, M. (2007). Perepletenie filogenticheskoy i kulturnoy istorii v ontogeneze [The interweaving of phylogenetic and cultural history in ontogenesis]. Kulturno-istoricheskaya psihologiya [Cultural and historical psychology], 3, 3-16. (rus.). 
11. Krymskyi, S. (2003). Zapyty filosofskykh smysliv [Queries of philosophical narratives]. Kyiv: Vyd. PARAPAN. (ukr.).

12. Kuievda, V. T. (2012). Refleksiia etnokulturnykh dominant v ukrainskii psykholohichnii dumtsi: istoryko-psykholohichnyi vymir [Reflection of ethnocultural dominants in Ukrainian psychological thought: historical and psychological dimension]. Istoryko-psykholohichna rekonstruktsiia psykholohichnoi dumky v etnokulturnomu vymiri: monohrafiia [Historical and psychological reconstruction of psychological thought in ethnocultural dimension: monograph]. V. T. Kuievdy, V. V. Turban (Ed.). Kirovohrad: Imeks-LTD, pp. 5-32. (ukr.).

13. Maksymenko, S. D. (2006). Heneza zdiisnennia osobystosti [Genesis of personality development]. Kyiv: Vyd. TOV «KMM». (ukr.).

14. Moskalenko, V. (2012). Znachennia henetychnoi metodolohii v doslidzhenni sotsializatsii osobystosti [The value of genetic methodology in the study of socialization of personality]. Sotsialna psykholohiia [Social psychology], 1-2, 3-10. (ukr.).

15. Moskovichi, S. (1995). Sotsialnyie predstavleniya: istoricheskiy vzglyad [Social views: a historical opinion]. Psihologicheskiy zhurnal [Psychological journal]. 1, 3-18; 2, 3-14. (rus.).

16. Novyi slovnyk inshomovnykh sliv: blyzko 40000 sl. i slovospoluchen [New dictionary of foreign words: about 40,000 words and phrases] (2008). L. I. Shevchenko (Ed.). Kyiv: ARII. (ukr.).

17. Porshnev, B. F. (1979). Sotsialnaya psihologiya i istoriya [Social psychology and history]. Moskva: Nauka. (rus.).

18. Romenets, V. A. (2006). Vchynok i postannia kanonichnoi psykholohii [The act and the emerging of canonical psychology]. Liudyna. Subiekt. Vchynok: Filosofsko-psykholohichni studii [Man. Subject. Act: Philosophical and psychological studies]. V. O. Tatenko (Ed.). Kyiv: Lybid, pp. 11-36. (ukr.).

19. Rubinshteyn, S. L. (1989). Osnovy obschey psihologii [Fundamentals of General Psychology]; V 2 t. T.1. Moskva: Pedagogika. (rus.).

20. Psykholohichna entsyklopediia [Psychological encyclopedia] (2006); avtor-uporiadnyk O. M. Stepanov. Kyiv: Akademvydav. (ukr.).

21. Teshfel, A. (1984). Eksperimenty v vakuume [Experiments in vacuum]. Sovremennaia zarubezhnaya sotsialnaya psihologiya [Modern foreign social psychology]. G. M. Andreeva, N.N. Bogomolova, L.A. Petrovskaya (Ed.). Moskva: Izd-vo Mosk. un-ta, P. 229-243. (rus.).

22. Tilli, Ch. (2009). Istoricheskaya sotsiologiya [Historical sociology]. Sotsiologicheskie issledovaniya [Sociological research], 5, 95-101. (rus.).

23. Tytarenko, T. M. (2014). Narysy do sotsialno-psykholohichnoi teorii osobystisnoho zhyttiekonstruiuvannia [Essays on the social and psychological theory of personal life-building]. Zbirnyk naukovyi statei Kyivskoho mizhnarodnoho universytetu i instytutu sotsialnoi ta politychnoi psykholohii NAPN Ukrainy [Collection of scientific articles of Kyiv International University and Institute of Social and Political Psychology of the National Academy of Pedagogical Sciences of Ukraine]. Seriia: «Psykholohichni nauky: problemy, zdobutky» [Series: «Psychological sciences: issues, achievements»]. Vypusk 5. Kyiv: KyMu, pp. 172-186. (ukr.).

24. Shamne, A. (2017). Interpretatsiia katehorii rozvytku u suchasnii psykholohii [Interpretation of the category of development in modern psychology]. Psykholohiia osobystosti [Psychology of personality], 1, 22-30. (ukr.).

26. Shkuratov, V. A. (2004). Novaya istoricheskaya psihologiya: monografiya [New historical psychology: monograph]. Rostov-na-Donuz: Izd-vo YuFU. (rus.).

26. Shtompka, P. (1996). Sotsiologiya sotsialnyih izmeneniy [Sociology of social change]. Moskva: Aspekt Press. (rus.).

27. Alexander, J. C. (2006). Cultural Pragmatics: social performance between ritual and strategy. Social Performance: Symbolic, Action, Cultural Pragmatics and Ritual. Jeffrey C. Alexander, Bernhand Giesen, Jason L. Mast. (Ed.). Cambridge: Cambridge Universitet Press, pp. 29-90.

28. Gergen, K. J. (2001). Social Construction in Context. London: SAGE Publications.

29. Meyerson, I. (2014). Les fonctions psychologiques et oeuvres. Paris: Albin Michel.

\section{Svitlana Lytvyn-Kindratiuk \\ HISTORICAL AND EVOLUTIONARY VECTOR OF STUDY OF PERSONALITY DEVELOPMENT IN MODERN PSYCHOLOGY}

The article deals with the personality development in the context of contemporary historical and evolutionary approaches in developmental psychology and social psychology. It advocates the relevance of enriching the methodological base of this search on the basis of the ideas of evolutionism, methodologies of general, developmental, social psychology, modern interdisciplinary platform of «developmental sciences» in foreign psychology. Methodological study of personality historiogenesis should be based on broadening the spectrum of essential characteristics of personality development. The methodological platform of «developmental sciences» allows you to include an innovative essential characteristic called contextuality to the already recognized characteristics, namely: the stages-of-man, the continuity of human development. It is believed that its introduction not only strengthens the evolutionary status of the principle of development, but also changes the way of 
determining the basic «unit» of development in this field. It is shown that the historiorization of personality development in the evolutionary perspective proceeds from the priority of the social and historical component of this process represented by the line of historiogenesis, that is, the development of personality in the diachronic aspect. It is argued that the accentuation of the value of social and psychological analysis within the mentioned line implies not only the addition to the spectrum of already known essential characteristics of the personality development of contextuality, but also the differentiation between generational interaction as a «unit» of the analysis of this process. The historical and evolutionary heuristic concept of «intergenerational interaction» is seen in the fact that its content is focused on taking into account the progression, heterochrony, contextuality of the historiogenesis of the personality in relational respect as the unity of processes of sociocultural constancy and variability, continuity and innovation of behavioral expressions. It is shown that the enrichment of the spectrum of essential characteristics of personality development in the diachronic aspect of the analysis allows to focus on the study of psychosocial development paired with historical and cultural ones, to give priority to the constancy-variability of these types of development, to go to the analysis of the range of forms of personality development, in particular, ritualized forms of behavior.

Keywords: historical and evolutionary approach, principle of development, «unit» of analysis of development, generation, intergenerational interaction, contextuality, historiogenesis of personality. 